\title{
Postcraniotomy Headache: Etiologies and Treatments
}

\author{
Corina Bello $^{1} \cdot$ Lukas Andereggen $^{1,2} \cdot$ Markus M. Luedi $^{1} \odot \cdot$ Christian M. Beilstein $^{1}$
}

Accepted: 14 February 2022 / Published online: 1 March 2022

(c) The Author(s) 2022

\begin{abstract}
Purpose of Review Postcraniotomy headache ( $\mathrm{PCH})$ is a highly underappreciated and very common adverse event following craniotomy.

Recent Findings Analgetic medication with opioids often interferes with neurologic evaluation in the acute phase of recovery and should be kept to a minimal, in general, in the treatment of chronic pain as well. We provide an update on the latest evidence for the management of acute and chronic PCH.

Summary Especially in the neurosurgical setting, enhanced recovery after surgery protocols need to include a special focus on pain control. Patients at risk of developing chronic pain must be identified and treated as early as possible.
\end{abstract}

Keywords Postcraniotomy headache $\cdot$ Neurosurgery $\cdot$ Acute pain $\cdot$ Chronic pain $\cdot$ Enhanced recovery after surgery

$\begin{array}{ll}\text { Abbreviations } \\ \text { COX } & \text { Cyclooxygenase } \\ \text { ERAS } & \text { Enhanced recovery after surgery } \\ \text { NSAIDs } & \text { Non-steroidal anti-inflammatory drugs } \\ \text { PCA } & \text { Patient-controlled analgesia } \\ \text { PCH } & \text { Postcraniotomy headache } \\ \text { PONV } & \text { Postoperative nausea and vomiting } \\ \text { QST } & \text { Quantitative sensory testing } \\ \text { TENS } & \text { Transcutaneous electric nerve stimulation } \\ \text { VGSC } & \text { Voltage-gated sodium channels }\end{array}$

This article is part of the Topical Collection on Acute Pain Medicine

Markus M. Luedi

markus.luedi2@insel.ch

Corina Bello

corina.bello@srrws.ch

Lukas Andereggen

lukas.andereggen@gmail.com

Christian M. Beilstein

Christian.Beilstein@insel.ch

1 Department of Anaesthesiology and Pain Medicine, Inselspital, Bern University, Hospital, University of Bern, Freiburgstrasse, 3010, Bern, Switzerland

2 Department of Neurosurgery, Kantonsspital Aarau, Aarau, Switzerland

\section{Background}

Anaesthesia for craniotomies requires well established interdisciplinary teamwork. The patient population is very diverse, as is the age distribution, ranging from paediatric to geriatric patients, and their respective diseases among others with brain tumors, aneurysms or stroke. In order to obtain the precision required for surgical procedures in the brain tissue, optimal planning and anaesthetic management are needed. Adequate sedation and pain relief enable a timely return to consciousness for adequate neurologic evaluation. The usual pain medicationgenerally opioids - can interfere with this process.

Postoperative pain is still very common today and requires a multimodal analgetic approach to pain management. Especially in the field of neuroanaesthesia, sound data is still scarce. We aim to provide an update on the most recent evidence regarding the management of acute and chronic headache attributed to craniotomy.

Postcraniotomy headache (PCH) is very common. Moderate to severe pain has been reported in up to 60 to $90 \%$ of patients undergoing craniotomy $[1,2]$. In addition, $30 \%$ of $\mathrm{PCH}$ patients suffer from chronic $\mathrm{PCH}$, with a tremendous effect on quality of life, especially in the very young as well the frail population [3]. Besides the major impact it has on daily life after discharge, $\mathrm{PCH}$ also influences in-hospital recovery. Pain causes high blood pressure, which can lead to an increased risk of intracranial bleeding and intracranial hypertension. These factors not only prolong hospital stay, but also increases mortality along with health care costs [4]. 
Headache attributed to craniotomy is defined by the Committee of the International Headache Society as PCH within 7 days after surgical craniotomy and lasting for less than 3 months [5]. If it persists for more than 3 months, it is considered persistent or chronic. However, there is an ongoing debate over whether the definition of acute postoperative pain should be extended to include onset 30 days after craniotomy instead of only 7 [6]. Interestingly, the occurrence of postoperative pain highly depends on the surgical approach being chosen [3].

The brain tissue itself does not have pain sensors, but intracranial pressure can cause dural irritation and subsequently trigger pain. Thus, while in many patients with intracranial lesions headache is not infrequently reported, response to surgery can be beneficial [7-9]. However, the scalp is innervated by cranial nerves, rami spinales dorsales and ventral rami (Fig. 1). The trigeminal, occipital, vagus and hypoglossus nerves also supply some parts of the head.

\section{Risk Factors for Postcraniotomy Headache}

There is evidence that there are multifactorial reasons for $\mathrm{PCH}$, including damage of the nerve branches but also the formation of neuromas [10], nerve entrapment in the scar, traction of the dura, formation of adhesions (from dura to bone, dura to muscle or dura to brain) or muscle incision. Aseptic meningitis and intracranial hypotension due to a cerebrospinal fluid leak are special types of acute postoperative complications that need to be ruled out to diagnose craniotomy-attributed headaches.

Other risk factors apart from location and size of the incision include young age, female gender, preoperatively existent pain, anxiety and depression [11], all of which could be addressed in the preoperative anaesthetic assessment.

Performing a broad risk assessment in every individual is of great importance. Depression, chronic pain (sensitivity) and anxiety are factors that have a great influence on postoperative pain. Patient education can greatly improve the experience

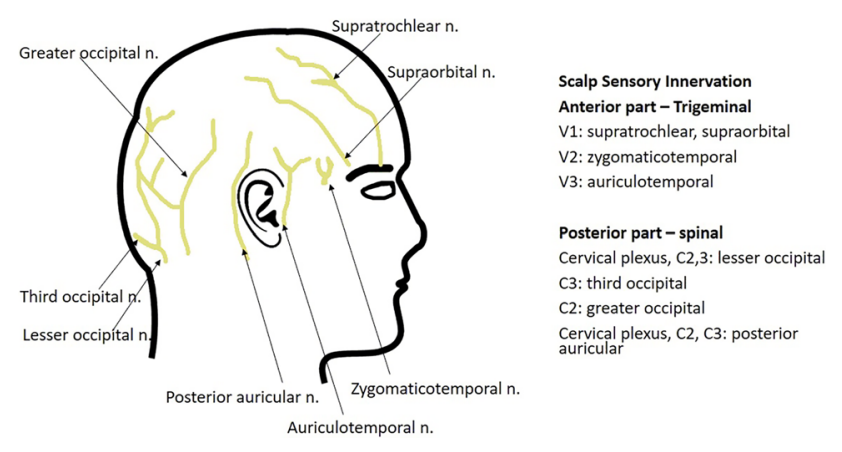

Fig. 1 Scematic of scalp innervation of pain by adequate information about the pain they have to expect. Patient history-including medications such as anticoagulants, glucocorticoids and anti-convulsants-needs to be assessed, and premedication, including gabapentin or acetaminophen, might be prescribed. These can have an opioidsparing effect, lessen the occurrence of delirium, improve sleep quantity and quality preoperatively, and lower the risk of postoperative nausea and vomiting (PONV). However, gabapentin may prolong the time to extubation and increase sedation requirements.

\section{Enhanced Recovery After Surgery}

As in other high-risk settings where protocols for enhanced recovery after surgery (ERAS) have been set up, preoperative patient evaluation needs to play a key role [12•]. There is strong evidence suggesting that preoperative quantitative sensory testing (QST) might help identify patients at risk of developing acute and chronic postoperative pain. Most techniques are easy to perform and should be implemented in a preoperative standardised protocol, just as routine neurologic, cardiac, pulmonary and laboratory exams have been standardised [13].

Only after solid preparation for the procedure and prehabilitation of the patient can intraoperative management be optimally coordinated, with the goal of reducing the risk of PCH. The choice of anaesthesia technique still depends on individual factors; however, intravenuous agents might be a better option when compared to inhalational agents such as sevoflurane, due to their better risk profile concerning haemodynamic stability, PONV [14] and inflammatory effects, all of which have an impact on postoperative pain $[15,16]$.

Adequately controlling pain while maintaining safety is very complex in operative neurosurgical procedures. Commonly used opioids such as fentanyl have many unwanted side effects, including sedation, nausea, vomiting and miosis. These can interfere with proper neurological exams postoperatively. Long-acting opioids such as fentanyl can interfere with intraoperative and postoperative neuro-monitoring [17]. Therefore, shorter-acting agents such as remifentanil might allow for better neurological assessment than longacting opioids. However, postemergence hyperalgesia is a common problem with remifentanil.

Some other medications might have a superior side effect profile. Paracetamol provides analgesia without sedation. Therefore, this agent would be good for clinical evaluation, but alone does not provide enough potency to mitigate pain. Non-steroidal anti-inflammatory drugs (NSAIDs) are commonly used pain medications that come in two distinct forms. Non-selective cyclooxygenase (COX) 1 and 2 inhibitors have a negative side effect profile including 
haemorrhage, renal failure and peptic ulcers [18]. The increased risk of bleeding and seizures can both lead to harmful events in neurosurgical procedures. Alternatively, selective COX2 inhibitors lead to less bleeding but seem to lack an opioid-sparing effect, limiting the tendency to switch to such costly options $[19,20]$. Lastly, metamizol might also be of interest but has an associated risk of drug-induced liver injury [21], and agranulocytosis and is therefor not recommended in every institution or patient setting.

Adjuvants such as lidocaine or dexmedetomidine can be used to spare opioids [22, 23, 24•].

Ketamine has been shown to improve cerebral perfusion; however, there is still a lack of evidence concerning the neurologically relevant side effects, such as cognitive disturbances, dizziness, visual problems and hallucinations [25]. When the side effects are severe, they can have a tremendous effect on this high-risk neurologic population, leading to limits on the use of ketamine as an adjuvant analgesic. Corticosteroids have been widely used for PONV prophylaxis. Their effect on pain is still unknown, but there are some studies showing benefits for pain management [26]. In glioblastomas, dexamethasone has been shown to have an oncogeneic effect on cancer cells, and therefore needs to be used with caution in this patient population [27•, 28]. In supratentorial surgery, lidocaine infusions have been tested and shown to have a positive effect in preventing postoperative pain. Finally, a sodium channel blocker generally used for the treatment of non-surgically related headache might also be beneficial in the treatment of acute PCH [29-31].

\section{Multimodal and Interdisciplinary Approaches}

Modern anaesthesia calls for a multimodal approach. Regional anaesthetic techniques are widely used in other specialties, such as abdominal wall surgical procedures, where local anaesthetic is inserted intrafascially in order to relieve pain postoperatively [32]. In craniotomy, scalp infiltration with a local anaesthetic is a promising technique. It has been shown to decrease the risk of bleeding when epinephrine is added to the local anaesthetic. Additionally, it has a positive impact on local haemodynamic response to skull fixation-for example, in the Mayfield frame-and is thereby effective in preventing persistent neuropathic pain. However, no benefit for acute postoperative pain has been found [17].

Direct singular nerve blocks can also be used for craniotomy and is standard in patients undergoing awake surgery along with intraoperative cortical stimulation. Such blocks are generally done "blindely", although ultrasound guidance is already standard for all other truncal and peripheral blocks [33]. Scalp nerves include supraorbital, auriculotemporal, occipital or zygomatico-temporal nerve branches. This technique has been shown to be more promising for acute postoperative pain than scalp infiltration. However, intraoperatively, there has not been any effect on anaesthetic requirements. Moreover, severe bradycardia was reported by Chowdhury et al. [34] after a trigeminal nerve block mitigated via trigeminocardiac reflex, pointing out the importance of close monitoring of vital parameters and evaluation of patient risk factors.

The application of subcutaneous sumatriptan is another technique which is still under investigation but might be promising [35].

Finally, an interdisciplinary approach might be the best solution to manage acute postoperative pain after all. As the surgeons work directly on the scalp, they can infiltrate the wound locally along the scar. The size of the incision is highly associated with the intensity of pain. Evidence assessing the effectiveness of postoperative compared to preoperative application of local infiltration of the wound is scarce; however, better emergence has been reported if the infiltration happens right before the end of the surgery, again showing the necessity for clear communication between the surgeon and the anaesthetist.

In the special setting of awake craniotomy, other promising techniques such as cingulum stimulation have been tested and shown to be effective in managing scalp pain intraoperatively [36]. Such techniques are highly efficient in providing adequate pain relief in the awake setting. There are minimal interacting side effects when it comes to neurologic evaluation of the patient. Postoperatively, however, there is a lack of evidence with regards to such techniques.

In the postoperative setting, there have been many studies discussing different approaches to managing PCH. Nonpharmacological treatments include cool packs, cryotherapy or head dressings [6]. The use of opioids produces the same problems already discussed in the intraoperative setting. There are case reports of methadone used as a primary analgesic agent with very good results in terms of pain control and side effects [37]. Patient-controlled analgesia (PCA) is a highly efficient method to provide adequate pain control. Nowadays, morphine has the best safety profile for postoperative use in this special setting [38, 39]. Some other studies using fentanyl as the analgesic agent in PCA have shown beneficial effects due to its shorter half-life compared to morphine [40]. NSAIDs might still offer a good additive choice to control postoperative pain. Nontheless, involving the whole care team and creating a solid pain evaluation and management plan is key to minimizing the development of chronic pain.

The pathophysiologic mechanisms behind chronic pain are complex, and on a molecular level remain unclear. There 
is evidence showing sensitisation of central neurologic pain perception and structural changes in receptive fields of neurons in the central nervous system. Migraine- or tension-like headaches are associated with hyperstimulation of GABA receptors in the raphe nuclei and changes in the serotonergic and haemodynamic systems [41]. Catecholaminergic nerves might also play a key role in patients suffering from chronic pain $[42,43]$.

In neurosurgery, the outcome of postoperative chronic pain is highly dependent on the preoperative assessment. Promising techniques such as QST are a great way to identify patients at risk [13]. Pressure pain threshold measurements can help assess patients at risk of developing chronic PCH [44]. Such early recognition of a population at risk helps focus discussion on adequate early treatment and multiple pain-desensitising options to actively stop or even prevent the development of $\mathrm{PCH}$.

Pharmacologic treatment modalities for chronic $\mathrm{PCH}$ include tricyclic drugs such as amitriptyline [45], as well as anti-convulsants. Valproate might help in migrainelike headaches [30], whereas gabapentin has been shown to be effective for neuropathic cranial pain [46, 47]. Carbamazepine [48] and lamotrigine [49] are other potential agents. Injection of botox for tension-type headache has been tried and showed beneficial effects in most chronic $\mathrm{PCH}$ patients $[50,51]$. The use of opioids-while very effective over the short term-should be limited considering the rapid increase in opioid-dependant patients worldwide [52].

Other promising pharmacological interventions which are under current investigation include drugs targeting NR2Bsubunit-selective N-methyl-D-aspartate receptors [53], voltage-gated sodium channels (VGSC) or tetrodotoxin-receptors, all of which play an important role in the development of chronic pain. However, pharmacologic evidence for such agents is still in its infancy.

\section{Implementation in Clinical Practice}

The patient population undergoing craniotomy includes a wide range of generations, starting already at a very young age. Managing pain in children is of great importance, and fast recovery is particularly warranted. The development of chronic PCH as defined by the International Headache Society might not be as common in this population as in the elderly [54], but still, PCH occurs in $42 \%$ of children within the first $72 \mathrm{~h}$ [55]. Especially in this population, opioid use is an important problem. Overall, there is a decreasing tendency toward self-reported opioid use in the paediatric population, but dependance on opioids is still problematic [56].

Table 1 Managing acute post-craniotomy headache

\begin{tabular}{|c|c|c|c|}
\hline Type of treatment & Evidence & Caveat & Reference \\
\hline Codeine & With paracetamol but not alone & Metabolization & $\begin{array}{l}\text { Sudheer et al. [61], Goldsack et al. } \\
\text { [62], Jeffrey et al. [63] }\end{array}$ \\
\hline $\begin{array}{l}\text { Morphine, long-acting } \\
\text { opioids }\end{array}$ & $\begin{array}{l}\text { Morphine superior to other opioids; } \\
\text { hydromorphine may be better }\end{array}$ & $\begin{array}{l}\text { Cerebral circulation and } \\
\text { metabolism impaired... }\end{array}$ & Sudheer et al. [61], Cold et al. [64] \\
\hline Tramadol & Good for acute postoperative pain & $\begin{array}{l}\text { Side effects (PONV; } \\
\text { drowsiness), less efficient } \\
\text { than morphine }\end{array}$ & Jeffrey et al. [63] \\
\hline PCA & $\begin{array}{l}\text { Very good with MO or fentanyl for pain } \\
\text { control, PONV, sedation }\end{array}$ & & Morad et al. [65] \\
\hline NSAID - non-selective & & & Kelly et al. [66] \\
\hline Ketamine & Improves cerebral perfusion intraoperatively & $\begin{array}{l}\text { Cognitive disturbances, } \\
\text { dizziness, visual problems, } \\
\text { hallus, effect on pain } \\
\text { unclear }\end{array}$ & $\begin{array}{l}\text { Mayberg et al. [14], Markovic- } \\
\text { Bozic et.al. [15], Himmelseher } \\
\text { et al. [25], Misra et al. [26] }\end{array}$ \\
\hline Lidocaine infusion & Postop acute pain reduced & & Peng et al. [22] \\
\hline Others & $\begin{array}{l}\text { Gabapentin (for better sleep and neuropathic } \\
\text { pain), amitriptyline (tension headache } \\
\text { chronic), valproate (migraine-like), } \\
\text { carbamazepine (chronic tension-like), } \\
\text { lamotrigine (neuralgia) }\end{array}$ & & $\begin{array}{l}\text { Silberstein et al. [30], Moore et al. } \\
\text { [51], Karst et al. [48], Sandner } \\
\text { et al. [49] }\end{array}$ \\
\hline $\begin{array}{l}\text { NR2B-subunit-selective } \\
\text { N-methyl-D-aspartate } \\
\text { receptor antagonists; } \\
\text { tetrodotoxin, VGSC }\end{array}$ & For prevention of chronic headache & & Perucca et al. [53] \\
\hline
\end{tabular}

NSAIDs non-steroidal anti-inflammatory drugs, PCA patient-controlled analgesia, PONV postoperative nausea and vomiting, VGSC voltagegated sodium channels 
Table 2 Post-craniotomy headache in children

\begin{tabular}{|c|c|c|c|c|c|c|}
\hline Author & Year & Study type & Arms & $\begin{array}{l}\text { Anaesthesia maintenance } \\
\text { technique }\end{array}$ & $\begin{array}{l}\text { Opioid use } \\
\text { (intraop and } \\
\text { postop) }\end{array}$ & Postop findings \\
\hline $\begin{array}{l}\text { Xing } \\
\text { et al. } \\
\text { [58] }\end{array}$ & 2019 & $\begin{array}{l}\text { Randomised } \\
\text { controlled } \\
\text { trial, } 320 \\
\text { children } \\
1-12 \mathrm{yr}\end{array}$ & $\begin{array}{l}\text { Control group normal } \\
\text { saline } 100 \mathrm{ml}, 2 \mathrm{ml} / \mathrm{h} \text {, } \\
\text { bolus } 0.5 \mathrm{ml} \text {; fentanyl } \\
0.1-0.2 \mu \mathrm{g} / \mathrm{k} \cdot \mathrm{h}, \\
\text { bolus } 0.1-0.2 \mu \mathrm{g} / \mathrm{kg} ; \\
\text { morphine } 10-20 \mu \mathrm{g} / \\
\mathrm{kg} \cdot \mathrm{h}, \text { bolus } 10-20 \mu \mathrm{g} / \\
\mathrm{kg} \text {; tramadol } 100- \\
400 \mu \mathrm{g} / \mathrm{kg} \cdot \mathrm{h}, \text { bolus } \\
100-200 \mu \mathrm{g} / \mathrm{kg}\end{array}$ & $\begin{array}{l}\text { Remifentanyl and } \\
\text { sevoflurane }\end{array}$ & $\begin{array}{l}\text { Rescue } \\
\text { medication: } \\
\text { ibuprofen, } \\
\text { morphine }\end{array}$ & $\begin{array}{l}\text { PCIA, NCIA with morphine safe and } \\
\text { most effective (less postoperative } \\
\text { pain, no increase in PONV, } \\
\text { respiratory depression, sedation), } \\
\text { most nausea in tramadol, less pain } \\
\text { in fentanyl and tramadol, risk factors } \\
\text { for moderate to severe pain: young } \\
\text { children, occipital craniotomy, } \\
\text { morphine treatment }\end{array}$ \\
\hline $\begin{array}{l}\text { Nesvick } \\
\text { et al. } \\
\text { [57] }\end{array}$ & 2020 & $\begin{array}{l}\text { Retrospective } \\
\text { cohort study }\end{array}$ & $\begin{array}{l}276 \text { patients under } \\
18 \mathrm{yr} \text { of age }\end{array}$ & & & $\begin{array}{l}\text { NSAID on postop day } 1 \text { do not } \\
\text { increase postoperative haemorrhage } \\
\text { requiring return to the operating } \\
\text { room or incidence of more-than- } \\
\text { minimal haemorrhage on routine } \\
\text { postoperative imaging }\end{array}$ \\
\hline $\begin{array}{l}\text { Xiong } \\
\text { et al. } \\
\text { [59] }\end{array}$ & 2020 & $\begin{array}{l}\text { Prospective, } \\
\text { randomised, } \\
\text { placebo- } \\
\text { controlled, } \\
\text { double- } \\
\text { blind trial }\end{array}$ & 180 patients age $1-12$ & $\begin{array}{l}\text { Preoperative scalp nerve } \\
\text { block with ropivacaine, } \\
\text { postoperative block, no } \\
\text { block }\end{array}$ & Sufentanil & $\begin{array}{l}\text { Under investigation - primary } \\
\text { outcome: pain score, consumption } \\
\text { of sufentanil within } 24 \mathrm{~h} \text {, additive } \\
\text { analgesic agents, length of hospital } \\
\text { stay, complications }\end{array}$ \\
\hline $\begin{array}{l}\text { Zhao } \\
\text { et al. } \\
{[60]}\end{array}$ & 2019 & $\begin{array}{l}\text { Prospective } \\
\text { randomized } \\
\text { controlled } \\
\text { trial }\end{array}$ & 100 patients aged $8-18$ & $\begin{array}{l}\text { Scalp nerve block with } \\
\text { ropivacaine + } \\
\text { methylprednisolone, } \\
\text { scalp nerve block with } \\
\text { ropivacaine only }\end{array}$ & & $\begin{array}{l}\text { Under investigation - primary } \\
\text { outcome: cumulative PCA-fentanyl- } \\
\text { dose within } 24 \mathrm{~h} \text {; secondary } \\
\text { outcome: postoperative Numerical } \\
\text { Rating Scale scores, pain control } \\
\text { satisfaction scores, length of stay and } \\
\text { adverse events }\end{array}$ \\
\hline
\end{tabular}

NSAIDs non-steroidal anti-inflammatory drugs, $P C A$ patient-controlled analgesia

NSAIDs are very widely used postoperatively in children, and have been shown to be safe and to provide adequate analgesia [57]. Just as in adult patients, morphinePCA is very promising in the acute setting [58]. There are studies evaluating the efficacy of ropivacaine for local scalp nerve blocks in the paediatric population, but there are still no results [59]. Other trials are assessing potential benefits of adding prednisolone to preemptive local ropivacaine scalp infiltrations [60]. There seems to be a local anti-inflammatory and anti-swelling effect without an oncogenic effect on glioblastomas [27•,28] of orally applied glucocorticoids such as dexamethasone [26] (Tables 1 and 2).

\section{Conclusion}

In summary, $\mathrm{PCH}$ is a highly underappreciated adverse event following craniotomy. Especially in the neurosurgical setting, ERAS protocols need to include a special focus on pain control. The aim should be to identify the population at risk of developing chronic pain conditions. Just as in other high-risk specialties such as cardiac surgery, a multimodal and interdisciplinary approach is a must. Specific methods to prevent transition from acute to chronic $\mathrm{PCH}$ include the preoperative identification of risk factors (depression, chronic pain and anxiety) with initiation of respective pharmacological therapy as soon as possible. In addition, acute pain after craniotomy must be managed proactively, to minimize the risk of transition to chronic pain. More evidence is needed, however, to define which anaesthetic techniques best serve the patient while allowing safe neurologic evaluation and providing adequate pain control. This will enable treating physicians to provide optimal care in this very diverse patient population.

Acknowledgements The authors thank Jeannie Wurz, Medical Editor, Department of Anaesthesiology and Pain Medicine, Bern University Hospital, for careful editing of the manuscript.

Author Contribution Corina Bello, Lukas Andereggen, Markus M. Luedi and Christian M. Beilstein conducted literature searches, wrote the article and approved the final version. 
Funding Open access funding provided by University of Bern.

Availability of Data and Material Not applicable.

Code Availability Not applicable.

\section{Compliance with Ethical Standards}

Ethics Approval This review article complies with ethical standards.

Consent to Participate Not applicable.

Consent for Publication Not applicable.

Conflict of Interest The authors declare no competing interests.

Human and Animal Rights and Informed Consent This article does not contain any studies with human or animal subjects performed by any of the authors.

Disclaimer All author have seen, reviewed and approved the final manuscript.

Open Access This article is licensed under a Creative Commons Attribution 4.0 International License, which permits use, sharing, adaptation, distribution and reproduction in any medium or format, as long as you give appropriate credit to the original author(s) and the source, provide a link to the Creative Commons licence, and indicate if changes were made. The images or other third party material in this article are included in the article's Creative Commons licence, unless indicated otherwise in a credit line to the material. If material is not included in the article's Creative Commons licence and your intended use is not permitted by statutory regulation or exceeds the permitted use, you will need to obtain permission directly from the copyright holder. To view a copy of this licence, visit http://creativecommons.org/licenses/by/4.0/.

\section{References}

Papers of particular interest, published recently, have been highlighted as:

- Of importance

1. De Benedittis G, Lorenzetti A, Migliore M, Spagnoli D, Tiberio F, Villani RM. Postoperative pain in neurosurgery: a pilot study in brain surgery. Neurosurgery. 1996;38(3):466-9; discussion 9-70. https://doi.org/10.1097/00006123-199603000-00008.

2. Peón AU, Diccini S. Postoperative pain in craniotomy. Rev Lat Am Enfermagem. 2005;13(4):489-95. https://doi.org/10.1590/ s0104-11692005000400005.

3. Rocha-Filho PA, Gherpelli JL, de Siqueira JT, Rabello GD. Postcraniotomy headache: characteristics, behaviour and effect on quality of life in patients operated for treatment of supratentorial intracranial aneurysms. Cephalalgia : an international journal of headache. 2008;28(1):41-8. https://doi.org/10.1111/j.14682982.2007.01465.x.

4. Leslie K, Troedel S, Irwin K, Pearce F, Ugoni A, Gillies R, et al. Quality of recovery from anesthesia in neurosurgical patients. Anesthesiology. 2003;99(5):1158-65. https://doi.org/10.1097/ 00000542-200311000-00024
5. Headache Classification Committee of the International Headache Society (IHS) The International Classification of Headache Disorders, 3rd edition. Cephalalgia: Int J Headache. 2018;38(1):1-211. https://doi.org/10.1177/0333102417738202.

6. Haldar R, Kaushal A, Gupta D, Srivastava S, Singh PK. Pain following craniotomy: reassessment of the available options. Biomed Res Int. 2015;2015: 509164. https://doi.org/10.1155/ 2015/509164.

7. Andereggen L, Frey J, Andres RH, El-Koussy M, Beck J, Seiler RW et al. 10-year follow-up study comparing primary medical vs. surgical therapy in women with prolactinomas. Endocrine. 2017;55(1):223-30. https://doi.org/10.1007/s12020-016-1115-2.

8. Andereggen L, Frey J, Andres RH, Luedi MM, Widmer HR, Beck J, et al. Persistent bone impairment despite long-term control of hyperprolactinemia and hypogonadism in men and women with prolactinomas. Sci Rep. 2021;11(1):5122. https:// doi.org/10.1038/s41598-021-84606-x.

9. Andereggen L, Mono ML, Kellner-Weldon F, Christ E. Cluster headache and macroprolactinoma: case report of a rare, but potential important causality. Journal of clinical neuroscience : official journal of the Neurosurgical Society of Australasia. 2017;40:62-4. https://doi.org/10.1016/j.jocn.2017.01.028.

10. Ferreira Kdos S, Dach F, Speciali JG. Scar neuromas as triggers for headache after craniotomy: clinical evidence. Arq Neuropsiquiatr. 2012;70(3):206-9. https://doi.org/10.1590/s0004-282x2012000300010.

11. Rimaaja T, Haanpää M, Blomstedt G, Färkkilä M. Headaches after acoustic neuroma surgery. Cephalalgia : an international journal of headache. 2007;27(10):1128-35. https://doi.org/10. 1111/j.1468-2982.2007.01410.x.

12.• Yang L, Kaye AD, Venakatesh AG, Green MS, Asgarian $\mathrm{CD}$, Luedi MM et al. Enhanced recovery after cardiac surgery: an update on clinical implications. Int Anesthesiol Clin. 2017;55(4):148-62. https://doi.org/10.1097/aia. 0000000000000168 . This article highlights the complex interaction of pain with other factors to be considered in enhanced recovery programmes.

13. Braun M, Bello C, Riva T, Hönemann C, Doll D, Urman RD, et al. Quantitative sensory testing to predict postoperative pain. Curr Pain Headache Rep. 2021;25(1):3. https://doi.org/10.1007/ s11916-020-00920-5.

14. Mayberg TS, Lam AM, Matta BF, Domino KB, Winn HR. Ketamine does not increase cerebral blood flow velocity or intracranial pressure during isoflurane/nitrous oxide anesthesia in patients undergoing craniotomy. Anesth Analg. 1995;81(1):84-9. https://doi.org/10.1097/ 00000539-199507000-00017.

15. Markovic-Bozic J, Karpe B, Potocnik I, Jerin A, Vranic A, Novak-Jankovic V. Effect of propofol and sevoflurane on the inflammatory response of patients undergoing craniotomy. BMC Anesthesiol. 2016;16:18. https://doi.org/10.1186/ s12871-016-0182-5.

16. Mordhorst C, Latz B, Kerz T, Wisser G, Schmidt A, Schneider A, et al. Prospective assessment of postoperative pain after craniotomy. J Neurosurg Anesthesiol. 2010;22(3):202-6. https:// doi.org/10.1097/ANA.0b013e3181df0600.

17. Dunn LK, Naik BI, Nemergut EC, Durieux ME. Post-craniotomy pain management: beyond opioids. Curr Neurol Neurosci Rep. 2016;16(10):93. https://doi.org/10.1007/s11910-016-0693-y.

18. Palmer JD, Sparrow OC, Iannotti F. Postoperative hematoma: a 5 -year survey and identification of avoidable risk factors. Neurosurgery. 1994;35(6):1061-4; discussion 4-5. https://doi.org/ 10.1227/00006123-199412000-00007.

19. Jones SJ, Cormack J, Murphy MA, Scott DA. Parecoxib for analgesia after craniotomy. Br J Anaesth. 2009;102(1):76-9. https:// doi.org/10.1093/bja/aen318. 
20. Rahimi SY, Vender JR, Macomson SD, French A, Smith JR, Alleyne $\mathrm{CH}$, Jr. Postoperative pain management after craniotomy: evaluation and cost analysis. Neurosurgery. 2006;59(4):852-7; discussion 7. https://doi.org/10.1227/01.neu.0000232646.35678.d8.

21. Sebode M, Lohse AW, Schramm C. Metamizole has been overlooked as a trigger for acute liver injury and acute liver failure. Deutsches Arzteblatt international. 2020;117(37):610. https:// doi.org/10.3238/arztebl.2020.0610a.

22. Peng Y, Zhang W, Kass IS, Han R. Lidocaine reduces acute postoperative pain after supratentorial tumor surgery in the PACU: a secondary finding from a randomized, controlled trial. J Neurosurg Anesthesiol. 2016;28(4):309-15. https://doi.org/10.1097/ ana.0000000000000230.

23. Rajan S, Hutcherson MT, Sessler DI, Kurz A, Yang D, Ghobrial M, et al. The effects of dexmedetomidine and remifentanil on hemodynamic stability and analgesic requirement after craniotomy: a randomized controlled trial. J Neurosurg Anesthesiol. 2016;28(4):28290. https://doi.org/10.1097/ana.0000000000000221.

24. Song J, Ji Q, Sun Q, Gao T, Liu K, Li L. The opioid-sparing effect of intraoperative dexmedetomidine infusion after craniotomy. Journal Neurosurg Anesthesiol. 2016;28(1):14-20. https:// doi.org/10.1097/ana.0000000000000190. This study established the intraoperative use of dexmedetomidine to reduce cumulative morphine consumption and adverse effects after craniotomy.

25. Himmelseher S, Durieux ME. Ketamine for perioperative pain management. Anesthesiology. 2005;102(1):211-20. https://doi. org/10.1097/00000542-200501000-00030.

26. Misra S, Parthasarathi G, Vilanilam GC. The effect of gabapentin premedication on postoperative nausea, vomiting, and pain in patients on preoperative dexamethasone undergoing craniotomy for intracranial tumors. J Neurosurg Anesthesiol. 2013;25(4):386-91. https://doi.org/10.1097/ANA.0b013e31829327eb.

27. Luedi MM, Singh SK, Mosley JC, Hassan ISA, Hatami M, Gumin J et al. Dexamethasone-mediated oncogenicity in vitro and in an animal model of glioblastoma. Journal Neurosurg. 2018;129(6):1446-55. https://doi.org/10.3171/2017.7.jns17668. This study describes the tumorigenic effect of dexamethasone on glioblastoma in vivo.

28. Luedi MM, Singh SK, Mosley JC, Hatami M, Gumin J, Sulman $\mathrm{EP}$, et al. A dexamethasone-regulated gene signature is prognostic for poor survival in glioblastoma patients. J Neurosurg Anesthesiol. 2017;29(1):46-58. https://doi.org/10.1097/ana. 0000000000000368.

29. Hendler N, Cashen A, Morrison C, Long D, Holliday M. Divalproex sodium and other medications for headache following craniotomy for acoustic neuroma. Headache. 1995;35(8):490-3. https://doi.org/ 10.1111/j.1526-4610.1995.hed3508490.x.

30. Silberstein SD. Divalproex sodium in headache: literature review and clinical guidelines. Headache. 1996;36(9):547-55. https:// doi.org/10.1046/j.1526-4610.1996.3609547.x.

31. Packard RC. Treatment of chronic daily posttraumatic headache with divalproex sodium. Headache. 2000;40(9):736-9. https:// doi.org/10.1046/j.1526-4610.2000.00128.x.

32. Sauter AR, Luedi MM. Effective treatment of pain by blocking techniques within a multimodal treatment concept. Anaesthesist. 2020;69(12):857-9. https://doi.org/10.1007/s00101-020-00834-2.

33. Luedi MM, Upadek V, Vogt AP, Steinfeldt T, Eichenberger U, Sauter AR. A Swiss nationwide survey shows that dual guidance is the preferred approach for peripheral nerve blocks. Sci Rep. 2019;9(1):9178. https://doi.org/10.1038/s41598-019-45700-3.

34. Chowdhury T, Baron K, Cappellani RB. Severe bradycardia during scalp nerve block in patient undergoing awake craniotomy. Saudi J Anaesth. 2013;7(3):356-7. https://doi.org/10.4103/1658$354 x .115344$.
35. Licina A, Russell J, Silvers A, Jin X, Denny J. Subcutaneous sumatriptan for the treatment of postcraniotomy pain (SUPS trial): protocol for a randomised double-blinded placebo controlled trial. BMJ Open. 2019;9(8): e032388. https://doi.org/10. 1136/bmjopen-2019-032388.

36. Bijanki KR, Manns JR, Inman CS, Choi KS, Harati S, Pedersen NP, et al. Cingulum stimulation enhances positive affect and anxiolysis to facilitate awake craniotomy. J Clin Investig. 2019;129(3):115266. https://doi.org/10.1172/jci120110.

37. Lutman B, Bloom J, Nussenblatt B, Romo V. A contemporary perspective on the management of post-craniotomy headache and pain. Curr Pain Headache Rep. 2018;22(10):69. https://doi. org/10.1007/s11916-018-0722-4.

38. Yu EH, Tran DH, Lam SW, Irwin MG. Remifentanil tolerance and hyperalgesia: short-term gain, long-term pain? Anaesthesia. 2016;71(11):1347-62. https://doi.org/10.1111/anae.13602.

39. Vadivelu N, Kai AM, Tran D, Kodumudi G, Legler A, Ayrian E. Options for perioperative pain management in neurosurgery. J Pain Res. 2016;9:37-47. https://doi.org/10.2147/jpr.s85782.

40. Vacas S, Van de Wiele B. Designing a pain management protocol for craniotomy: a narrative review and consideration of promising practices. Surg Neurol Int. 2017;8:291. https://doi.org/10. 4103/sni.sni_301_17.

41. Marcus DA. Serotonin and its role in headache pathogenesis and treatment. Clin J Pain. 1993;9(3):159-67. https://doi.org/ 10.1097/00002508-199309000-00002.

42. Cavallotti D, Artico M, De Santis S, Iannetti G, Cavallotti C. Catecholaminergic innervation of the human dura mater involved in headache. Headache. 1998;38(5):352-5. https://doi.org/10. 1046/j.1526-4610.1998.3805352.x.

43. Artico M, Cavallotti C. Catecholaminergic and acetylcholine esterase containing nerves of cranial and spinal dura mater in humans and rodents. Microsc Res Tech. 2001;53(3):212-20. https://doi.org/10.1002/jemt.1085.

44. Luedi MM, Schober P, Hammoud B, Andereggen L, Hoenemann C, Doll D. Preoperative pressure pain threshold is associated with postoperative pain in short-stay anorectal surgery: a prospective observational study. Anesth Analg. 2021;132(3):65662. https://doi.org/10.1213/ane.0000000000005072.

45. Diamond S, Baltes BJ. Chronic tension headache-treated with amitriptyline-a double-blind study. Headache. 1971;11(3):110 6. https://doi.org/10.1111/j.1526-4610.1971.hed1103110.x.

46. Moore KA, Baba H, Woolf CJ. Gabapentin-actions on adult superficial dorsal horn neurons. Neuropharmacology. 2002;43(7):107781. https://doi.org/10.1016/s0028-3908(02)00226-5.

47. Serpell MG. Gabapentin in neuropathic pain syndromes: a randomised, double-blind, placebo-controlled trial. Pain. 2002;99(3):557-66. https://doi.org/10.1016/s0304-3959(02)00255-5.

48. Karst M, Rollnik JD, Fink M, Reinhard M, Piepenbrock S. Pressure pain threshold and needle acupuncture in chronic tension-type headache-a double-blind placebo-controlled study. Pain. 2000;88(2):199_ 203. https://doi.org/10.1016/s0304-3959(00)00315-8.

49. Sandner-Kiesling A, Rumpold Seitlinger G, Dorn C, Koch H, Schwarz G. Lamotrigine monotherapy for control of neuralgia after nerve section. Acta Anaesthesiol Scand. 2002;46(10):12614. https://doi.org/10.1034/j.1399-6576.2002.461014.x.

50. Rollnik JD, Karst M, Fink M, Dengler R. Botulinum toxin type A and EMG: a key to the understanding of chronic tension-type headaches? Headache. 2001;41(10):985-9. https://doi.org/10. 1046/j.1526-4610.2001.01193.x.

51. Zwart JA, Bovim G, Sand T, Sjaastad O. Tension headache: botulinum toxin paralysis of temporal muscles. Headache. 1994;34(8):458 62. https://doi.org/10.1111/j.1526-4610.1994.hed3408458.x.

52. Matta BF, Menon DK, Turner JM. Textbook of neuroanaesthesia and critical care. Cambridge University Press. 2000. 
53. Perucca E. Pharmacological and therapeutic properties of valproate: a summary after 35 years of clinical experience. CNS Drugs. 2002;16(10):695-714. https://doi.org/10.2165/00023210200216100-00004.

54. Maxwell LG, Buckley GM, Kudchadkar SR, Ely E, Stebbins EL, Dube C, et al. Pain management following major intracranial surgery in pediatric patients: a prospective cohort study in three academic children's hospitals. Paediatr Anaesth. 2014;24(11):1132-40. https://doi.org/10.1111/pan.12489.

55. Teo JH, Palmer GM, Davidson AJ. Post-craniotomy pain in a paediatric population. Anaesth Intensive Care. 2011;39(1):8994. https://doi.org/10.1177/0310057x1103900115.

56. Gaither JR, Leventhal JM, Ryan SA, Camenga DR. National trends in hospitalizations for opioid poisonings among children and adolescents, 1997 to 2012. JAMA Pediatr. 2016;170(12):1195-201. https://doi.org/10.1001/jamapediatrics.2016.2154.

57. Nesvick CL, Oushy S, Daniels DJ, Ahn ES. Safety of immediate use of nonsteroidal antiinflammatory drugs after pediatric craniotomy for tumor. Journal of neurosurgery Pediatrics. 2020:1-7. https://doi.org/10.3171/2020.4.peds2055.

58. Xing F, An LX, Xue FS, Zhao CM, Bai YF. Postoperative analgesia for pediatric craniotomy patients: a randomized controlled trial. BMC Anesthesiol. 2019;19(1):53. https://doi.org/10.1186/ s12871-019-0722-x.

59. Xiong W, Li L, Bao D, Wang Y, Liang Y, Lu P, et al. Postoperative analgesia of scalp nerve block with ropivacaine in pediatric craniotomy patients: a protocol for a prospective, randomized, placebo-controlled, double-blinded trial. Trials. 2020;21(1):580. https://doi.org/10.1186/s13063-020-04524-7.

60. Zhao C, Jia Y, Jia Z, Xiao X, Luo F. Pre-emptive scalp infiltration with ropivacaine plus methylprednisolone versus ropivacaine alone for relief of postoperative pain after craniotomy in children (RP/MP vs RP): a study protocol for a randomised controlled trial. BMJ Open. 2019;9(6): e027864. https://doi.org/ 10.1136/bmjopen-2018-027864.

61. Sudheer PS, Logan SW, Terblanche C, Ateleanu B, Hall JE. Comparison of the analgesic efficacy and respiratory effects of morphine, tramadol and codeine after craniotomy. Anaesthesia. 2007;62(6):555-60. https://doi.org/10.1111/j.1365-2044.2007. 05038.x.

62. Goldsack C, Scuplak SM, Smith M. A double-blind comparison of codeine and morphine for postoperative analgesia following intracranial surgery. Anaesthesia. 1996;51(11):1029-32. https:// doi.org/10.1111/j.1365-2044.1996.tb14997.x.

63. Jeffrey HM, Charlton P, Mellor DJ, Moss E, Vucevic M. Analgesia after intracranial surgery: a double-blind, prospective comparison of codeine and tramadol. Br J Anaesth. 1999;83(2):245-9. https:// doi.org/10.1093/bja/83.2.245.

64. Cold GE, Felding M. Even small doses of morphine might provoke "luxury perfusion" in the postoperative period after craniotomy. Neurosurgery. 1993;32(2):327. https://doi.org/10.1097/ 00006123-199302000-00032.

65. Morad AH, Winters BD, Yaster M, Stevens RD, White ED, Thompson RE, et al. Efficacy of intravenous patient-controlled analgesia after supratentorial intracranial surgery: a prospective randomized controlled trial. Clinical article. J Neurosurg. 2009;111(2):343-50. https://doi.org/10.3171/2008.11.jns08797.

66. Kelly KP, Janssens MC, Ross J, Horn EH. Controversy of nonsteroidal anti-inflammatory drugs and intracranial surgery: et ne nos inducas in tentationem? Br J Anaesth. 2011;107(3):302-5. https://doi.org/10.1093/bja/aer230.

Publisher's Note Springer Nature remains neutral with regard to jurisdictional claims in published maps and institutional affiliations. 